\title{
The Impact of Advertising and Sales Promotion on Initial Purchase, Addition and Change of Existing GSM Networks by Students in Nigeria
}

\author{
Hindu Jibril Amin ${ }^{1} \&$ Abdullahi Mohammed Bashir ${ }^{2}$ \\ ${ }^{1}$ Department of Business Administration, Nigerian Turkish Nile University, Nigeria \\ ${ }^{2}$ Department of Accounting, Usumanu Danfodiyo University Sokoto, Nigeria \\ Correspondence: Hindu Jibril Amin, Department of Business Administration, Nigerian Turkish Nile University, \\ Plot 681, Cadastral Zone C- 00 Research and Institution Area, Jabi Airport, Road Bypass Abuja, FCT, Nigeria. \\ Tel: 234-803-600-6609. E-mail: hinduamin68@yahoo.com
}

Received: July 21, 2014

doi:10.5539/ijbm.v9n10p161
Accepted: September 1, 2014

Online Published: September 25, 2014

\begin{abstract}
This Study sets out to find the impact of advertising and sales promotion on the decision made by students on initial purchase, additions and change of GSM services in Nigeria. 500 Students were selected from 4 different Universities within the north - east to constitute the population of the study. Questionnaires and Oral interview were used in collecting the data for the research. The finding reveals that advertisement and sales promotions played a role in influencing change of existing networks due to reliability of service and cost effectiveness. The results will help the service providers in building confidence in the minds of their consumers in terms of choice of a particular GSM service.
\end{abstract}

Keywords: advertising, sales promotion, choice criteria

\section{Introduction}

Communication is a vital engine of any economy; it is an essential infrastructure that promotes the development of other sectors such as agriculture, education, industry, health, banking, defence, transportation and tourism. It is indispensable in times of national emergency or natural disasters. It considerably reduces the risks and rigors of travel and rural - urban migration. Communications system is a key ingredient for promoting rapid socio-economic and political development of any nation. Such a system must be universally accessible and cost effective. Advertising and sales Promotion are part of the elements of communication.

\subsection{Advertising}

Advertising is a subset of promotion mix, which is one of the 4 p's in the marketing mix, that is product, price, place and promotion. As a promotional strategy, advertising serves as a major tool in creating product awareness in the mind of a potential consumer to take eventual purchase decision.

Advertising, sales promotion and public relations are mass-communication tools available to marketers. Advertising through all mediums influence audiences, but television is one of the strongest medium of advertising and due to its mass reach; it can influence not only the individual's attitude, behavior, life style, exposure and in the long run, even the culture of the country. (Latif \& Abideen, 2011)

(Huang et al., 2012) are of the view that consumers are not only sensitive to price but also the firm's advertising efforts. Polo et al 2011, shows that mass advertising exert a significant influence on the probability of terminating an existing incumbent relationship.

\subsubsection{Advertising Effectiveness}

In addition to focusing on the centrality of the advertising message and the significance of the executional strategy, earlier research into advertising effectiveness suggested that there is a particular order in which consumers respond to advertisements. The argument suggests that advertisements, therefore, can be constructed to achieve particular responses according to the nature of the communications and marketing objectives desired (Vaughn, 1980; Olney et al., 1991; Rossiter et al., 1991). 
According to this sequential ordering of effects, if advertisements are to be successful in influencing consumer behaviour, they must first lead consumers through a series of reception stages. These stages, usually described as cognitive, affective and conative, are essentially, and in some cases, entirely, hierarchical in nature (Maclnnis \& Jaworski, 1989; Barry \& Howard 1990).

This is an information-processing model that prioritises the message, the executional strategy and the relevance to the consumer of the brands, products or services featured in the advertisement. It assumes that if the message is clear and it is delivered effectively it will be interpreted appropriately (Eagleton, 1983; Scott, 1994; Meyers-Levy \& Malaviya, 1999). The role of consumers in this configuration is dependent on specific individual needs and particular responses to the advertisement. It is a process that is deliberate, conscious and, presumably, predictable.

\subsubsection{Self-Confidence}

There are various theories that relate to advertising and consumer behaviour, one of them is the theory by Abraham Maslow proposes a motive hierarchy, his approach is based on four premises: That 1) All human acquire a similar set of motives through generic endowment and social interaction. 2) Some motives are more basic or critical than others. 3) The more basic motives must be satisfied to a minimum level before other motives are activated. 4) As the basic motives become satisfied, more advanced motives come into play. Self Esteem is one of the motive proposed by Maslow which indicated the desire for status, superiority, self respect and prestige. People in that category of need would always want to show themselves out for recognition, and would want to help others.

Previous studies have attested that self-confidence or self-esteem is related to caring about others' wellbeing (Caprara \& Steca, 2005; Penner, Dovidio, PiUavin, \& Schroeder, 2005; Penner, Fritzsche, Craiger, \& Freifeld, 1995). Helping others is motivated by a desire to maintain and enhance one's self-confidence or self-esteem (Basil and Weber, 2006; Clary et al., 1998; Crocker and Luhtanen, 1990; Staub, 1978). It is likely that individuals who perceive themselves competent are engaged in prosocial behaviours because they believe in their capacity to effectively allocate their resources to others in need. Self-confident people are more likely to exercise control over the events that influence their lives. For those with self confidence, their efforts to buy products tied to social causes or charities would be considered as a way of helping others.

To understand the importance of emotion in driving behaviour, Hall and others briefly re review the P.E.M model. As described previously in the Journal of Advertising Research (Hall, 2002), this is a theory based on how advertising affects the consumer's perception, experience, and memory. They believe it is the best comprehensive, fully developed theory of advertising that is consistent with the modern psychology and neuroscience consents: People respond to emotion first and reason last-feel, do, think, not think-feel-do.

The model breaks the consumer's response to advertising into three functional phases: framing perception, enhancing experience, and organizing memory. The most important characteristic of this model is that emotions, feelings, affect, and experience are more important than cognition in each phase of the process. Perception is a dependant variable, influenced by advertising and experience as well as by the consumer's priors. Multiple feedback loops then connect advertising and perception at every stage of the process.

In the Pre-Experiences phase, the critical function of advertising is to "frame perception" Exposing a consumer to an advertisement has the following effects.

1) Creates an expectation for the brand. This tells the consumer what the brand is, and how it fits into her portfolio of needs - is it a place to keep your savings or an after school snack?

2) Creates a sense of anticipation for what the brand can do for her. Will it make her feel financially secure, fulfilled as a mother, satisfy a craving? Note that this is not a reason for buying or a unique selling preposition. It is the emotional force driving the consumer toward the brand. It is why great food advertisements make you hungry, great car advertisements give us the feeling of driving, and great travel advertisements make us feel like we are on vacation.

3) Provides a rational interpretation for the anticipation it generates-either explicit, with product specifications or features described in objective terms, or implicit, an implied benefit that translates as an objective reason to buy. This is not necessarily a rational reason for buying, although it can be. It is really the consumer's logical explanation to himself (and anybody else who bothers to ask) for the decision he has already made on an emotional basis.

4) The next phase in the sequence is "enhancing experience." When the consumer is actually using the product or service. 
5) There is strong experimental foundation that demonstrates advertising's ability to enhance the consumer's actual sensory experience with brands. Hall, 2002 hypothesize that advertising enhances social experience, which is at the core of most service exchanges.

There is the Post-Experience exposure phase. For most advertised brands, most of the time, this is more common than Pre-Experience exposure because established brands advertise much more than new brands. In this phase, advertising's key function is "organizing memory". Cueing is analogous to expectation in the pre-experience phase. The advertisement provides verbal, visual, and aural cues that help the audience recall the brand. Cueing can be effective cues, particularly if based on visual images, sounds, or music. Remembering is the analog of anticipation. It carries more emotional impact than cueing. Remembering is the process by which advertisement reshape consumers' long-term memory of the brands and helps the consumer remember the brand in ways the advertiser, not the consumer, chooses (Hall, 2002).

Finally, the advertisement stimulates a cognitive interpretation of the brand's relevance and significance. The advertisement not only influences the consumer to feel that the sensory or social experience was a good one, but it also provides reasons to believe that it was. And if the advertisement fails to provide or imply a reason-to-believe, the consumer's "interpreter" will supply one (Gazzaniga, 1998), which customers experience after their purchases.

\subsection{Sales Promotion}

Promotion is one of the techniques to attract consumers to purchase more or try a product or service. Severe outcomes of promotion included sales increased, quality of stock used and attract new consumers. For example, price promotion refers to temporary price reduction, which offers to consumers. The characteristic is the retailer would label a specific percentage or cash saving for the products or services.

Palazon and Ballester, (2011), Observes that the effectiveness of different promotional tools, price discounts and premiums depends on the level of deal proneness. An effective and well planned promotion can stimulate consumer's buying intensions but the success of the promotion would be contingent on deal proneness. So is vital to identify the target consumer and more effective instruments to attract them in designing a promotional campaign.

Nowlis, (2000) also proposes that sales promotion and the choice set composition have compensatory effects on brand switching. Selecting the effective instruments and identifying the target customer is also very important part of any promotional activity.

\subsubsection{The Effects of Bundle of Promotions}

A vast body of research documents the effects of price promotions on consumers' purchase behaviour and distinguishes between choice effects (what to buy) and incidence/quantity effects (whether and how much to buy in the category). Price promotions induce consumers to switch items and buy more and earlier in the category, otherwise known as the acceleration effect (e.g., Ailawadi \& Neslin, 1998; Bell, Chiang, \& Padmanabhan, 1999; Neslin, 2002)

In the context of bundle promotions, the quantity decision influences the choice decision; therefore, we conceptualize consumers' choices given their category purchase quantities. Specifically, they distinguish between two cases in which the consumer's total purchase quantity (1) equals or exceeds the bundle quantity requirement or (2) is lower than the bundle quantity requirement.

In the first case, consumers have a clear economic motive to switch. Allocating a large enough share of their total purchase quantity in the category to one or more bundle promoted items enables them to take advantage of the bundle discount. Because a bundle promotion involves a range of items, consumers may consider switching to several bundle items simultaneously. However, the decision to switch to one bundle item is not made independently of the decision to switch to another. Buying one bundle item may enhance the likelihood that the consumer will also switch to another bundle item in an attempt to meet the bundle quantity requirement.

In other words, when the utility of one bundle item rises, a consumer's willingness to allocate the required purchase quantity to the bundle range will increase, thus leveraging the choice probabilities of all bundle items compared with those of non bundle items. Inspired by the industrial organization literature on bundling (e.g., Martin, 1999; Whinston, 1990),

They refer to this phenomenon as the "leverage effect." From a behavioural perspective, this leverage effect bears some resemblance to the "cluster effect," a context effect in which adding an item to a choice set helps similar items in the choice set (Sivakumar, 1995). In contrast to the cluster effect, however, the 
bundle-promotion leverage effect does not stem from the items' similarity but rather from the consumer's understanding that constraining his or her selection of items to the limited bundle set will lead to a monetary benefit.

When the total purchase quantity is lower than the bundle quantity requirement, a rational consumer might be expected to refrain from any promotional reaction because the bundle discount is out of reach. However, they believe that consumers may still respond to the bundle discount as a result of both positive and negative psychological effects. On the positive side, consumers may process the promotional information only partially and notice the discount but ignore the quantity requirement. Previous research has demonstrated that consumers do not always engage in detailed information processing when confronted with price promotions (Inman, McAlister, \& Hoyer, 1990). Consequently, the bundle discount may be able to entice even those consumers who do not actually benefit from the promotion. They call this phenomenon the "discount communication effect."

On the negative side, if consumers process all bundle information and thus realize that they do not qualify for the discount, they may switch away from the bundle-promoted items. Feinberg, Krishna, and Zhang (2002) find evidence of a betrayal effect, by which consumers switch to another brand if they become aware that their favorite brand offers deals to other selected consumers. Their research is grounded in relative deprivation and perceived fairness theories.

Another explanation for potential negative switching effects emerges from the reference price literature (Kopalle \& Lindsey-Mullikin, 2003; Mayhew \& Winer, 1992). By offering a bundle at a reduced price, the seller provides an external reference price, which may reduce the consumer's willingness to purchase the items at the regular price.

In any case, according to both the betrayal and the reference price rationales, a bundle discount may induce negative switching behaviour among consumers who do not qualify for the bundle promotion. Because the existing literature does not provide any indication about which effect will prevail - the positive discount communication or the negative betrayal/reference effect. From the foregoing, the present research was evident that consumers are willing to choose the services that offered promotions rather than their competitors.

\subsection{Choice Criteria}

Consumer choices are complex. Choice requires that the consumer confronts several brands and selects one, rejecting all others. To make choices consumers may use many types of processes, both compensatory and no compensatory. In contrast to forming intentions, inter brand comparisons become particularly important in choice. Thus, consumers may eliminate brands early in their processing using simplifying, non-compensatory processes that compare brands (Wright, 1975).

The best-known model of behaviour prediction, Fishbein, and Ajzen's, (1975) theory of reasoned action, was developed to predict volitional actions (those under personal control) from behavioural intentions. It explicitly excluded habitual and other behaviours for which people may be unable to carry out their intentions. Subsequently, Azjen (1985) extended the model into the theory of planned behaviour to address non-volitional actions. He added a predictor, perceived behavioural control, to represent the extent to which people have the resources, skills, and opportunities for performance. In so doing, Ajzen (2002) claimed that, "measures of intention and perceived control should fully mediate the effects of earlier experiences on later action" (p. 108). In this view, repetition of action does not change the decision making mechanisms determining that action. With repetition, decision making simply becomes more efficient so that attitudes and intentions are activated automatically and guide action without conscious supervision.

In contrast to the planned behaviour approach, other predictive models have recognized the role of habit dispositions (i.e., Eagly, \& Chaiken, 1993; Ouellette \& Wood, 1998; Triandis, 1977, 1980) - that is, because context cues can trigger habitual responses relatively automatically, habits are not thought to require supporting intentions. Triandis (1977, p. 205) explained: When a behaviour is new, untried, and unlearned, the behaviouralintention component will be solely responsible for the behaviour, while, when the behaviour is old, well-learned, or over learned and has occurred many times before in the organism's life span, it is very likely to be under the control of the habit component.

In this view, intentions are not required to guide many frequently practiced actions. The potential for habitual responses to override intentions will not be evident for many everyday actions, given the positive correlation that typically exists between strength of intentions and strength of habits (as represented by frequency of past performance). In one estimate across 33 studies, this relation was moderate in size, Ouellette \& Wood, 1998). Of course, the relation will not always be positive, as is evident with so-called bad or unwanted habits. When 
intentions and habits conflict in this way, people typically can exert regulatory control and act on their intentions as opposed to habit dispositions. Triandis's (1977) prediction is that people typically do not do so. The tendency for habits to run off despite intentions to act otherwise is understandable given that inhibition of automatically cued responses requires regulatory control, and that such control appears to be a limited resource that is easily depleted in daily life (Muraven \& Baumeister, 2000).

\section{Methodology}

The Method used in collecting Date for the research is both purposive and simple random sampling. Purposive sampling was used in selecting the Universities of study, that is Universities in the north - eastern part of Nigeria They were a total of eight Universities in the sub - region. Four out of the eight universities were selected which constitute all the categories of the Universities in Nigeria. Public own Universities, State own Universities and Private own Universities. Questionnaires were used in collecting the data for the research. Interview was also administered to both students and service providers to supplement some of the questions asked in the questionnaire. The primary data came mainly from the questionnaire. The questionnaire consists of different categories of questions relating to advertising, sales promotion and consumer choice.

The entire students of the selected Universities in the north-east constitute the population of the study. It is however, difficult to undertake study on such a large population, because it will be too cumbersome and costly. Therefore, a random sample of 500 students was selected across the various universities of study.

The GSM service providers, which formed part of the population include all the service providers in Nigeria, that operate within the north eastern sub - region at the time the data was collected. The service Providers were: Mtn, Glo and Zain Nigeria.

In order to find the impact of advertisement and sales promotion in relation to student's choice of GSM services, options from the questionnaires were ranked, where respondents can choose more than one option as their response. The responses were summarized in tabular form. Frequencies and percentages were used in analyzing the results from the tables.

\section{Data Analysis}

Table 1. Distribution of respondents based on the use of other networks apart from the initial one, and if advertising and sales promotion played any role

\begin{tabular}{lllll}
\hline & $\begin{array}{l}\text { Yes } \\
\text { Frequency }\end{array}$ & \% & $\begin{array}{l}\text { No } \\
\text { Frequency }\end{array}$ & \% \\
\hline $\begin{array}{l}\text { Whether respondents used other networks } \\
\text { Whether advertising played any role }\end{array}$ & 384 & 82.05 & 120 & 25.64 \\
& 355 & 75.85 & 131 & 27.99 \\
Whether sales promotion played any role & & & & \\
& 374 & 79.91 & 93 & 19.87 \\
Total & $\mathbf{1 , 1 1 3}$ & & $\mathbf{3 4 4}$ & \\
\hline
\end{tabular}

Source: Fieldwork.

Table 2. Distribution of respondents based on initial purchase and additions

\begin{tabular}{|c|c|c|c|c|}
\hline & \multicolumn{2}{|c|}{ Initial Purchase } & \multicolumn{2}{|c|}{ Additional purchase } \\
\hline & Frequency & $\%$ & Frequency & $\%$ \\
\hline Zain & 177 & 37.82 & 154 & 32.91 \\
\hline Glo & 81 & 17.31 & 159 & 33.97 \\
\hline Mtn & 179 & 38.25 & 145 & 30.98 \\
\hline Total & 437 & & 458 & \\
\hline
\end{tabular}

Source: Fieldwork. 
Table 3. Distribution of respondents based on change or additions of network

\begin{tabular}{lllllll}
\hline & Maiduguri & Bauchi & Abti & Gombe & Total & \% \\
Change & 73 & 26 & 29 & 15 & 143 & 30.56 \\
Additions & 116 & 29 & 21 & 44 & 120 & 25.64 \\
Total & $\mathbf{1 8 9}$ & $\mathbf{5 5}$ & $\mathbf{5 0}$ & $\mathbf{5 9}$ & $\mathbf{2 6 3}$ & \\
\hline
\end{tabular}

Source: Fieldwork.

Table 4. Distribution of respondents based on whether they have changed from one network to another

\begin{tabular}{lllllll}
\hline & Maiduguri & Bauchi & Abti & Gombe & Total & $\mathbf{\%}$ \\
Glo to Mtn & 10 & 04 & - & - & 14 & 11.86 \\
Zain to Mtn & 47 & - & - & - & 47 & 39.83 \\
Mtn to Glo & 05 & - & 09 & 03 & 17 & 14.41 \\
Zain to Glo & 06 & 05 & 17 & - & 28 & 23.73 \\
Mtn to Zain & - & - & - & 12 & 12 & 10.17 \\
Total & $\mathbf{6 8}$ & $\mathbf{0 9}$ & $\mathbf{2 6}$ & $\mathbf{1 5}$ & $\mathbf{1 1 8}$ & \\
\hline
\end{tabular}

Source: Fieldwork.

Table 5. Distribution of respondents based on the choice of network in relation to advertising and sales promotion

\begin{tabular}{lllll}
\hline & Advertising & \multicolumn{3}{c}{ Sales promotion } \\
& Frequency & $\mathbf{\%}$ & Frequency & \% \\
\hline Zain & 423 & 90.38 & 407 & 86.97 \\
Glo & 392 & 83.76 & 440 & 94.02 \\
Mtn & 462 & 98.72 & 438 & 93.59 \\
Total & $\mathbf{1 , 2 7 7}$ & & $\mathbf{1 , 2 8 5}$ & \\
\hline
\end{tabular}

Source: Fieldwork.

From table 1, respondents indicated the use of other networks by more than $80 \%$ of the respondents. Sales promotion has more influence on the use of other networks by respondents. The initial purchases of the GSM services as shown in table 2 are Mtn, then Zain. Mtn is indicated to be the most patronized followed by Zain, while the most added lines are Glo and Zain respectively. Advertising and sales promotion affect both initial and additional purchases. Change is also said to be affected by advertising and sales promotion

Table 3 shows that students change their lines rather than adding another one, this might be because most of them use one network. Movement from one network to the other shows that Zain losses more customers than the other networks. Most of the respondents moved from Zain to Mtn, (39\%) While 23\% moved from Zain to Glo. Glo to Mtn 11\%. This was shown on table 4.

It is indicated on table 5 that Glo do more on sales promotion than any other network, while Mtn do more of advertisement.

\section{Discussion of Findings}

About $82 \%$ indicated that they use other networks. The reason given by the respondents for such action is due to disappointment or dissatisfaction with the initial line or superior services and incentives provided by the other network. Only a quarter of the respondents stuck to their initial network. It is possible that these categories of respondents are not avid users of GSM. Such category of customers would not crave for incentives and are not likely to be frequently disappointed if services are disrupted or inefficient because of their low usage of the service.

Survey results suggested that advertising and sales promotion influence both addition and change of network services. The study revealed that Globacom was the most frequently added lines, because it is the newest of these networks studied and they seem to have an aggressive expansion strategy.

It is therefore, no surprise that when MTN was introduced to the sub-region its wider distribution of services nationwide appealed to customers, hence, the movement to MTN. Indeed in many of the adverts by the MTN network the slogan is: "MTN everywhere you go". This highlights their wider network coverage. 
Advertisement certainly plays a role in the choice of GSM network based on the informative, appealing and captivating nature of the advert. Previous studies by Lastovicka (1983) and Zinkhan and Burton (1989) have highlighted the importance of an advertisement being entertaining for it to be effective. Entertaining adverts tend to attract consumers to a particular brand.

Sales promotion can be defined as: 'marketing activities usually specific to a time period, place or customer group, which encourage a direct response from consumers or marketing intermediaries, through the offer of additional benefits, 'Previous research has demonstrated that consumers do not always engage in detailed information processing when confronted with price promotions (Inman, McAlister, and Hoyer 1990). Consequently, the bundle discount may be able to entice even those consumers who do not actually benefit from the promotion. They call this phenomenon the "discount communication effect."

Cost of utilizing services of the GSM network is the most important factor that influenced decision to change from one network to the other. GSM services are obviously very expensive relative to land-line or fixed wireless network. Therefore, customers have to go for the cheapest network whenever possible.

Every business activity must start with the understanding of customer needs. It is very important for organizations to be aware of what the mobile Internet can do for customers. In this new economy, customers are more demanding for better services with special features and reasonable prices (Kalakota, 2002, Sylywotzky \& Morrison, 2002). The proper information is one of the features that customer are looking for. Evans and Wurster (1998) introduce two useful concepts about information: richness, which refers to the quality of information, and reach, which refers to the number of customers that receive a certain type of information. They mention that there is a trade-off between reach and richness. it is therefore, important to set out a strategy in order to achieve your set goals.

\section{Summary, Conclusion and Recommendation}

Advertisement and sales promotions has influence on initial purchase and additions, about $80 \%$ of respondents agree that advertisement and sales promotions played a role in their addition of network. Majority of the respondents either use their initial network or change to another network for reliability of services and cost effectiveness.

It was concluded that: Advertisement and sales promotions has influence on initial purchase and additions, this was indicated by the respondents when $80 \%$ of them agree that advertisement and sales promotions played a role in their addition of network. Out of the total number of respondents, 143 changed their lines. 120 added other lines, which means that majority of the respondents either use their initial network or change to another network for reliability of services. Most of the students were found to have been using a single network.

It is therefore recommended that the service providers should use the television in advertising their services

The benefits of the service should be stressed in all advertisements, such as the bonuses and free gifts available, because what customers are actually looking for, are the benefits.

Sales promotions should be done at shorter intervals, since it was found to induce more purchase from customers.

Service providers should try and retain their existing customers and prevent them from moving to other networks by giving them special offers.

\section{References}

Ailawadi, K. L., \& Scott., A, N. (1998). The effect of Promotion on Consumption: Buying More and Consuming it faster. Journal of Marketing Research, 35, 390-398. http://dx.doi.org/10.2307/3152036

Ajzeen., I. (2002). Residential effects of past on later Behavior: Habitation and Reasoned action perspectives. Personality and Social Psychology Review, 6, 107-122. http://dx.doi.org/10.1207/S15327957PSPR0602_02

Ajzen, I. (1985). From intentions to Actions: A Theory of Planned Behaviour. In Action Control: From Cognition to Behaviour. New York: Springer-Verlag. http://dx.doi.org/10.1007/978-3-642-69746-3_2

Barry, T. E., \& Howard, D. J. (1990). A review and critique of the hierarchy of effects in advertising. International Journal of Advertising, 9(2), 121-135.

Basil, D. Z., \& Weber, D. (2006). Value Motivation and Concern for Appearance: The Effect of Personality Traits on Responses to Corporate Social Responsibility. International Journal of Nonprofit Voluntary Sector Marketing 11(1), 61-72. http://dx.doi.org/10.1002/nvsm.38

Bell, D. R., Jeongwen, C., \& Padmanabhan, V. (1999). The Decomposition of Promotional Response: An 
empirical Generalization. Marketing Science, 18(4), 504-526. http://dx.doi.org/10.1287/mksc.18.4.504

Caprara, G. V., \& Steca, P. (2005). Self-Efficacy Beliefs as Determinants of Prosocial Behaviour Conductive to Life Satisfaction across Age. Journal of Social and Clinical Psychology, 24(2), 195-217. http://dx.doi.org/10.1521/jscp.24.2.191.62271

Clary, E. G., Snyder, M., Ridge, R. D., Copeland, J., Stukas, A. A., Haugen, J., \& Miene, P. (1998). Understanding and Assessing the Motivations of Volunteers: A Functional Approach. Journal of Personality and Social Psychology, 74(6), 1516-1530. http://dx.doi.org/10.1037/0022-3514.74.6.1516

Crocker, J., \& Luhtanen, R. (1990). Collective Self-Esteem and Ingroup Bias. Journal of Personality and Social Psychology, 58(11), 60-67. http://dx.doi.org/10.1037/0022-3514.58.1.60

Eagleton, T. (1983). Literary Theory: An Introduction. Minneapolis: University of Minnesota Press.

Eagley, A. H. (1993). And Shelly Chaiken. The Psychology of Attitudes. Orland, FL: Harcourt Brace Jovanovich.

Feinberg, F., Aradhna, M. K., \& John, Z. (2002). Do we Care What Others Get? A behaviorist Approach to Targeted Promotions. Journal of Marketing Research, 39, 277-291. http://dx.doi.org/10.1509/jmkr.39.3.277.19108

Fishbein, M., \& Icek, A. (1975). Belief, attitude, Intention and Behaviour: An Introduction to Theory and Research. MA: Addison-Wesley. Foundations.

Gazzaniga, M. S. (1998). The Mind's Past Berkeley. CA: University of California Press.

Hall, B. F. (2002). A New Model for Measuring Advertising Effectiveness. Journal of Advertising Research, 42(2), 23-32.

Huang, J., Leng, M., \& Liang, L. (2012). Recent Developments in Dynamic Advertising Research. European Journal of Operational Research, 2(20), 591-609. http://dx.doi.org/10.1016/j.ejor.2012.02.031

Inman, J, Jeffrey, L. M., \& Wayne, D. H. (1990). Promotion Signal: Proxy for a Price Cut? Journal of Consumer Research, 17(1), 1-22. http://dx.doi.org/10.1086/208538

Kalakota, R., \& Robinson, M. (2002). M-Business: The Race to Mobility. (R. Donnelly \& Sons Company). McGraw-Hill Companies Inc.

Kopalle, P. K., \& Joan, L. M. (2003). The Impact of External Reference Price on Consumer Price Expectation. Journal of Retailing, 79(4), 225-236. http://dx.doi.org/10.1016/j.jretai.2003.09.002

Lastovicka, J. L. (1983). Convergent and Discriminant Validity of Television Commercial Rating Scales. Journal of Advertising, 12(2), 14-23. http://dx.doi.org/10.1080/00913367.1983.10672836

Latif., A., \& Abideen, Z. U. L. (2011). Effects of Television on Children: A Pakistani Perspective. Journal of Economics, Finance and Administrative Sciences, 30, 38-49.

MacInnis, Deborah, J., \& Bernard, J. J. (1989). Information Processing from Advertisement: towards an integrative framework. Journal of Marketing, 53(4), 1-23. http://dx.doi.org/10.2307/1251376

Martin, S. (1999). Strategic and Welfare Implications of Bundling. Economic Letters, 62(3), 371-376. http://dx.doi.org/10.1016/S0165-1765(98)00236-5

Mayhew, G. E., \& Russel, S, W. (1992). An Empirical Analysis of Internal and External Reference Prices Using Scanner Data. Journal of Consumer Research, 19(1), 62-70. http://dx.doi.org/10.1086/209286

Meyers, L. J., \& Malariya, P. (1999). Consumers' processing of Persuasive Advertisements: An integrative frame work of persuasion Theories. Journal of Marketing, 63, 45-60. http://dx.doi.org/10.2307/1252100

Muraven, M., \& Baumeister, R. F. (2000). Self-Regulation and Depletion of Limited Resources:' Does Self-Control Resemble a Muscle? Psychological Bulletin, 126, 247-259. http://dx.doi.org/10.1037/0033-2909.126.2.247

Neslin, S. (2002). Sales Promotion (1st ed.). Marketing Science Institute (MSI).

Nowlis, S. M., \& Simonson, I. (2000). Sales Promotion and the Sales Context as Competing Influences on Consumer decision making. Journal of Consumer Psychology, 9(1), 1-16. http://dx.doi.org/10.1207/s15327663jcp0901_1

Olney, T. J., Batra, R., \& Holbrook, M. B. (1991). Consumer responses to advertising: the effects of ad content, emotions, and attitude toward the ad on viewing time. Journal of Consumer Research, 17(4), 440-453. http://dx.doi.org/10.1086/208569 
Palazon., M., \& Ballester, E. D. (2011). The expected Benefit as Determinant of Deal Prone Consumers: Response to Sales Promotion. Journal of Retailing and Consumer Services, 18, 542-547. http://dx.doi.org/10.1016/j.jretconser.2011.07.004

Penner, L, A., Dovidio, J. F., Pillavin, J. A., \& Schroeder, D. A. (2005). Prosocial Behaviour: Multilevel $\begin{array}{lllll}\text { Perspectives. Annual } & \text { review }\end{array}$ http://dx.doi.org/10.1146/annurev.psych.56.091103.070141

Penner, L. A., Fritzsche, B. A., Craiger, J. P., \& Freifeld, T. R. (1995). Measuring the Prosocial Personality. In J. N. Butler \& C. D. Spielberger (Eds.), Advances in Personality Assessment (Vol. 10). Hillsdale, NJ, Hove: Erlbaum.

Polo, Yolande, F., Sese, J., \& Verhoef, P. C. (2011). The effect of Pricing and Advertising on Consumer Retention in a Liberalizing Market. Journal of Interactive Marketing, 25, 201-214. http://dx.doi.org/10.1016/j.intmar.2011.02.002

Quellette., J. A., \& Wood, W. (1998). Habit and Intention in everyday life: The Multiple Processess by which Past Behavior Predicts Future Behavior. Psychology Bulletin, 124, 54-74. http://dx.doi.org/10.1037/0033-2909.124.1.54

Rossiter, J. R., Percy, L., \& Donovan, R. J. (1991). A better advertising planning grid. Journal of Advertising Research, 31(5), 111-121.

Scott, L. M. (1994). Images in advertising: the need for a theory of visual rhetoric. Journal of Consumer Research, 21(2), 252-270. http://dx.doi.org/10.1086/209396

Sivakumar., K. (1995). Role of Price Quality tiers on the Cluster effect in Brand Choice. Marketing Letters, 6(4), 265-273. http://dx.doi.org/10.1007/BF00996190

Slywotzky, J., \& Morrison, D. (1998). How Digital is your Business? (1st ed.). New York.

Staub, E. (1978). Positive Behaviour and Morality. New York: Academic Press.

Triandis, H. C. (1977). International Behavior Monetary.

Triandis, H. C. (1980). Values, Attitudes and Interpersonal Behavior.

Vaughn, R. (1991). How advertising works: a planning model. Journal of Advertising, 20(5), 27-33.

Whinston., M. D. (1990). Tying Foreclosure and Exclusion. American Economic Review, 80(4), 837-859.

Wright, P. L. (1975). Consumer Choice Strategies: Simplifying Versus Optimising. Journal of Marketing Research, 11, 60-67. http://dx.doi.org/10.2307/3150659

Zinkhan, G. M., \& Burton, S. (1989). An Examination of three Multidimentional Profiles for assessing Consumer Reactions to Advertisements. Journal of Advertising, 18(4), 6. http://dx.doi.org/10.1080/00913367.1989.10673162

\section{Copyrights}

Copyright for this article is retained by the author(s), with first publication rights granted to the journal.

This is an open-access article distributed under the terms and conditions of the Creative Commons Attribution license (http://creativecommons.org/licenses/by/3.0/). 